$\begin{array}{lc}\begin{array}{c}\text { Australian Journal of } \\ \text { Crop Science }\end{array} & \text { A JCS } \\ \text { AJCS 14(10):1549-1554 (2020) } & \text { ISSN:1835-2707 }\end{array}$

AJCS 14(10):1549-1554 (2020)

ISSN:1835-2707

doi: 10.21475/ajcs.20.14.10.p1633

\title{
Influence of nitrogen rates on the persistence of ryegrass (Lolium multiflorum L.) forage production
}

\author{
Diógenes Cecchin Silveira' ${ }^{182}$, Juliana Medianeira Machado², Luiz Pedro Bonetti², Ivan Ricardo Carvalho ${ }^{5}$, \\ Vinícius Jardel Szareski ${ }^{3}$, Maurício Horbach Barbosa ${ }^{3}$, Tiago Corazza da Rosa ${ }^{3}$, Afonso Henrique Schaeffer', \\ Eder Alexandre Minski da Motta ${ }^{4}$, Natâ Balssan Moura ${ }^{5}$
}

\author{
${ }^{1}$ University of Passo Fundo, Passo Fundo, RS, Brazil \\ ${ }^{2}$ University of Cruz Alta, Cruz Alta, RS, Brazil \\ ${ }^{3}$ Federal University of Pelotas, Pelotas, RS, Brazil \\ ${ }^{4}$ Federal University of Rio Grande do Sul \\ ${ }^{5}$ Northwestern Regional University of the State of Rio Grande do Sul, ljuí, RS, Brazil
}

*Correspondent author: carvalho.irc@gmail.com

Abstract

This work aimed at evaluating the influence of nitrogen rates on the persistence of ryegrass forage production during four agricultural years. The experiment was performed in the experimental area of the University of Cruz Alta, Brazil. The experimental design was complete randomized blocks, with four agricultural years (2013, 2014, 2015 and 2016) $\times$ four harvesting times (first, second, third and fourth) $\times$ seven nitrogen doses $\left(0,50,100,150,200,250\right.$ and $\left.300 \mathrm{~kg} \mathrm{ha}^{-1}\right)$, arranged in four replicates. The application of nitrogen on natural re-sowing ryegrass promotes the increase in dry biomass production across agricultural years. The use of nitrogen as topdressing showed little effect on the persistence of ryegrass plants in the four years of study. The efficiency of nitrogen utilization was inversely proportional to the increment of the nitrogen doses used. It is fundamental to understand the behavior of nitrogen fertilization in pastures with natural re-sowing and its effects on the persistence of the plants throughout agricultural years, as well as their participation in the sustainability of agricultural activity.

Keywords: biomass production, Lolium multiflorum, urea, Brazil.

Abbreviations: OM_Organic matter; P_phosphorus; K_potassium; AL_aluminum; Ca_Calcium; Mg_magnesium; H+Al_potential acidity; CEC_effective cation exchange capacity; Cu_cupper; Zn_zinc; B_boron

\section{Introduction}

The increasing demand for animal products requires a constant rise in yields, which is limited by the productivity and quality of natural pastures that currently occupy about $50 \%$ of the growing areas of Rio Grande do Sul state (Overbeck et al., 2013). In this context, it is sought the comprehension about forage species ecophysiology through the adequate establishment of plants in the pasture ( $\mathrm{Da}$ Silva and Nascimento Junior, 2007). Currently, the adoption of crop-livestock integration systems is an effective alternative that allows the production of vegetal and animal species concomitantly in the property, at the same physical space. Thereby, it is possible to increase yields and incomes of the agricultural sector, as well as the whole system's sustainability (Hirakuri et al., 2012; Cordeiro et al., 2015). Among the available forage alternatives, annual ryegrass (Lolium multiflorum Lam.) is highlighted. It is characterized as a widely used grass in southern Brazil, mainly in Rio Grande do Sul, where it presents high nutritional quality and adequate forage potential (Barth Neto et al., 2013). This grass presents the highest wintering area sown due to its high productive potential, adaptability to intrinsic edaphoclimatic conditions of the growing environment, as well as suitability for natural re-sowing (Confortin, 2009; Carvalho et al., 2016). The ability of natural re-sowing enhances the utilization of seeds produced by forage species, especially at the end of spring and after physiological maturation, where they remain in contact with the soil throughout the summer period.

Among several factors that influence forage yield, the characteristics of the species, the management of areas with natural re-sowing, the costs of forage production, and the period of pasture utilization lead to profitability maximization (Barbosa et al., 2008). However, there is a need to define which are the responses for nitrogen management under these conditions, and thus, to define their influence on plant growth and development (Taiz and Zeiger, 2013).

By properly considering nitrogen management, it will be possible to economically maximize the activity, increase forage yield, reduce losses and contamination of the environment, use efficient practices that allow greater vegetative growth of forage plants and phytomass accumulation (Assmann et al. 2002). Considering the lack of information regarding the adequate nitrogen management 
in ryegrass pastures with natural re-sowing, this work aimed at evaluating the influence of nitrogen rates on the persistence of ryegrass forage production during four agricultural years.

\section{Results and Discussion}

The analysis of variance revealed significance for the interaction between agricultural years $x$ harvesting times $x$ nitrogen doses for dry biomass production, indicating that forage production was not constant in function of the evaluated factors. The key issue that involves the utilization of natural re-sowing species is precisely its persistence throughout agricultural years, where this study presents the impact of nitrogen doses on this specie management. It is important to note that annual ryegrass is not naturally adapted to re-sowing, however the intense cultivation in this region has led to the formation of a seed bank benefited by the low costs of pasture formation.

Parsons et al. (2011) revealed that there are innumerable factors that influence growth and development of forage species, such as tolerance and persistence to edaphoclimatic stresses, their influence on yield and quality of the forage produced, however, these authors give special importance for dry biomass production. In general, it can be observed that dry biomass production was higher in the first year of evaluation (2013), showing subsequent reductions (Table 2). This information becomes extremely important because this crop was managed under natural re-sowing, and nitrogen doses presented little influence on this trait for all years of evaluation.

Probably, the adopted management had negative impact on plant population in the subsequent years. It could indicate the need of sowing over the years, besides, employ a correct management in this area. The low response for nitrogen doses in the dry matter production in subsequent years might be due to management errors related to time, frequency and intensity of harvests (OST, 2013). For Barbosa et al. (2008), the production of tillers from natural re-sowing presents high association with final canopy height of plants from the previous year (Barbosa et al., 2007), as pastures maintained with residual height above $12 \mathrm{~cm}$ ensure adequate over seeding. In this study, the average residual height was $10 \mathrm{~cm}$, which allowed the annual re-sowing with high forage yields, but indirectly reduced yields over the years, gradually.

In study conducted with annual ryegrass in the state of Rio Grande do Sul, increases in the real yield of seeds were obtained, which was attributed to the incidence of the fungus Helminthosporium graminicola, resulting in the decrease of the magnitude of tillers per plant (Medeiros and Nabinger, 2001). Despite this reduction of dry biomass yield across agricultural years, it is noteworthy that yields were higher than those verified in the literature that contrasts this species with nitrogen doses (Mittelmann et al., 2010; Szareski et al., 2016). Seed production is directly associated with nitrogen applications between 60 and $130 \mathrm{~kg} \mathrm{ha}^{-1}$ under temperate conditions (Youngberg, 1980; Young et al., 1996; Sicard, 1995; Ahrens and Oliveira, 1997). The yield of perennial ryegrass (Lolium perene L.) seeds during five years of study in the United States was not influenced by nitrogen doses up to $200 \mathrm{~kg} \mathrm{ha}^{-1}$ (Rowarth et al., 1998). In general, nitrogen doses promoted increases in dry biomass production within each agricultural year, and through harvesting times (Figure 2), confirming the importance of this nutrient for growth and development of grasses (Taiz and Zieger, 2013).

Nitrogen utilization efficiency (NUE) is an important factor for evaluating the efficiency and sustainability of nitrogen fertilization, since it describes the plant's ability to utilize available nitrogen and direct it to biomass production (Seepaul et al., 2016). In general, the highest NUE was obtained through $50 \mathrm{~kg}$ of urea per hectare in the agricultural year. This efficiency was reduced according to increments in nitrogen doses (Table 3). Reductions of 17,4; 28,$0 ; 31,5 ; 38,8$ and $37,8 \%$ were observed for the respective doses 100,150, 200, 250 and $300 \mathrm{~kg}$ of urea per hectare in the agricultural year, compared to the highest efficiency.

The lowest NUE were inversely proportional to the highest nitrogen fertilizing doses, as studies show that this tendency is due to the increase of nitrogen losses by leaching and volatilization (Costa et al., 2016). Furthermore, NUE is dependent on intrinsic characteristics of the forage species and genotypes used, development stage, doses applied and their fractioning, frequency of use, environmental factors and soil fertility (Carambula, 1977). Nitrogen is characterized as one of the most difficult nutrients to be effectively managed, because the source commonly used in Brazil is urea, and losses up to $30 \%$ are evidenced due to volatilization (Cantarella, 2007). Therefore, it is necessary to express these results in order to provide information that aids the sustainable economic management of forage activity, aiming to increase biomass production, and minimize economic losses and environment harms.

The Soil Chemistry and Fertility Commission of the state of Rio Grande do Sul and Santa Catarina revealed changes, in 2016, regarding nitrogen $(N)$ recommendations. It indicates the fractioning of this nutrient according to the proportion of organic matter in the soil (Table 1), characteristics of the soil and species, as well as yield expectations, where natural re-sowing ryegrass presented high yields (Figure 3 ). However, it is necessary to know the adequate dose of this nutrient capable of economically maximize forage production, reduce losses and enhance sustainability of agricultural activity and animal production.

\section{Materials and Methods}

\section{Conduction of study}

The experiment was performed in the experimental area of the University of Cruz Alta, at coordinates $28^{\circ} 33^{\prime} 47.09$ "S and $53^{\circ} 37^{\prime} 22.49^{\prime \prime} \mathrm{W}$, with altitude of 452 meters. The soil in the region (Table 1 ) is classified as Distrophic Red Latosol (Embrapa, 2013). The climate is characterized as subtropical humid (Cfa) according to Köppen (Figure 1), with average annual rainfall of $1300 \mathrm{~mm}$ and average air temperature of 20 -C.

\section{Experimental design}

The experimental design was complete randomized blocks, with four agricultural years (2013, 2014, 2015 and 2016) x four harvesting times (first, second, third and fourth) $x$ seven nitrogen doses $\left(0,50,100,150,200,250\right.$ and $\left.300 \mathrm{~kg} \mathrm{ha}^{-1}\right)$, arranged in four replicates. The experimental units consisted of $25 \mathrm{~m}^{2}$. The applications of nitrogen (Urea to $46 \%$ of nitrogen) were performed in fractionated topdressing with four applications. The first one was performed during the 
Table 1. Physical and chemical attributes of the environment of study.

\begin{tabular}{llllllllll}
\hline Clay $(\%)$ & $\mathrm{pH}$ water & $\mathrm{SMP}$ index & $\mathrm{OM}(\%)^{1}$ & $\mathrm{P}^{2}$ & $\mathrm{~K}^{3}$ & $\mathrm{Al} \mathrm{exc}^{4}$ & $\mathrm{Ca} \mathrm{exc}{ }^{5}$ & $\mathrm{Mg} \mathrm{exc}^{6}$ \\
\hline 72 & 5.1 & 5.4 & 3.5 & 14.9 & 94.0 & 0.8 & 2.6 & 0.8 & \\
\hline $\mathrm{H}+\mathrm{Al}^{7}$ & $\mathrm{CTC}_{\text {effective }}{ }^{8}$ & $\mathrm{CEC}_{\mathrm{pH} 7,0}{ }^{9}$ & $\mathrm{~V}^{10}$ & $\mathrm{~m}^{11}$ & $\mathrm{~S}^{12}$ & $\mathrm{Cu}^{13}$ & $\mathrm{Zn}^{14}$ & $\mathrm{Mg}^{15}$ & $\mathrm{~B}^{16}$ \\
\hline 8,5 & 4.4 & 12.2 & 30.0 & 18.0 & 5.6 & 3.9 & 1.6 & 19 & $\mathrm{n} . \mathrm{d}$
\end{tabular}

$\mathrm{OM}$ - Organic matter; ${ }^{2} \mathrm{P}$ - phosphorus; ${ }^{3} \mathrm{~K}$ - potassium; ${ }^{4} \mathrm{Al}$ - aluminum; ${ }^{5} \mathrm{Ca}-\mathrm{Calcium} ;{ }^{6} \mathrm{Mg}$ - magnesium; ${ }^{7} \mathrm{H}+\mathrm{Al}$ - potential acidity; ${ }^{8} \mathrm{CEC}$ effective-cation exchange capacity determinedon soil pH; ${ }^{\circ} \mathrm{CEC} \mathrm{PH} 7,0$-cation exchange capacity

Table 2. Dry biomass production of natural re-sowing ryegrass under different doses of nitrogen fertilization during four agricultural years. Dry biomass $\left(\mathrm{kg} \mathrm{ha}^{-1}\right)$

$0 \mathrm{~kg} \mathrm{ha}^{-1}$

\begin{tabular}{|c|c|c|c|c|}
\hline \multirow{2}{*}{ Cuts } & \multicolumn{4}{|c|}{ Years } \\
\hline & 2013 & 2014 & 2015 & 2016 \\
\hline 10 & $5296.00 \mathrm{bA}$ & $3287.20 \mathrm{bA}$ & $5544.40 \mathrm{abA}$ & $2730 \mathrm{aA}$ \\
\hline $2^{\circ}$ & $4085.20 \mathrm{bB}$ & $1776.80 \mathrm{bB}$ & $8534.40 \mathrm{aA}$ & $5071.6 \mathrm{aAB}$ \\
\hline зо & $3422.00 \mathrm{bAB}$ & $1240.80 \mathrm{bB}$ & $5796.80 \mathrm{abA}$ & $4769.6 \mathrm{aA}$ \\
\hline 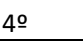 & $10908.80 \mathrm{aA}$ & $8330.40 \mathrm{aAB}$ & $4590.80 \mathrm{bB}$ & $4769.6 \mathrm{aB}$ \\
\hline \multicolumn{5}{|c|}{$50 \mathrm{~kg} \mathrm{ha}^{-1}$} \\
\hline \multirow{2}{*}{ Cuts } & \multicolumn{4}{|c|}{ Years } \\
\hline & 2013 & 2014 & 2015 & 2016 \\
\hline 10 & $6688.00 \mathrm{bAB}$ & $5443.20 \mathrm{bB}$ & $10338.00 \mathrm{abA}$ & $5028.40 \mathrm{bB}$ \\
\hline 20 & $10786.00 \mathrm{bAB}$ & $4271.20 \mathrm{bB}$ & $13866.40 \mathrm{aA}$ & $11859.60 \mathrm{aAB}$ \\
\hline 3은 & $7841.60 \mathrm{bA}$ & $4444.80 \mathrm{bB}$ & $8712.80 \mathrm{bcA}$ & $8546.80 \mathrm{aA}$ \\
\hline 40 & $18993.60 \mathrm{aA}$ & $12615.60 \mathrm{aB}$ & 7538.40 cB & $8546.80 \mathrm{aB}$ \\
\hline \multicolumn{5}{|c|}{$100 \mathrm{~kg} \mathrm{ha}^{-1}$} \\
\hline \multirow{2}{*}{ Cuts } & \multicolumn{4}{|c|}{ Years } \\
\hline & 2013 & 2014 & 2015 & 2016 \\
\hline 10 & $12060.00 \mathrm{bA}$ & $6008.80 \mathrm{bA}$ & $11870.40 \mathrm{bA}$ & $7641.20 \mathrm{bA}$ \\
\hline 2o & $11486.80 \mathrm{bcA}$ & 8994.80 bB & $18958.00 \mathrm{aA}$ & $12748.80 \mathrm{aA}$ \\
\hline зо & $9460.40 \mathrm{cB}$ & $7308.80 \mathrm{bC}$ & $15435.20 \mathrm{aA}$ & $9582.80 \mathrm{aAB}$ \\
\hline 4은 & $23709.20 \mathrm{aA}$ & $19461.20 \mathrm{aB}$ & 7792.40 cC & $9582.80 \mathrm{aC}$ \\
\hline \multicolumn{5}{|c|}{$150 \mathrm{~kg} \mathrm{ha}^{-1}$} \\
\hline \multirow{2}{*}{ Cuts } & \multicolumn{4}{|c|}{ Years } \\
\hline & 2013 & 2014 & 2015 & 2016 \\
\hline 10 & $13740.00 \mathrm{bA}$ & $7878.80 \mathrm{bB}$ & $11823.60 \mathrm{bA}$ & $8989.20 \mathrm{bB}$ \\
\hline 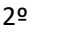 & $13585.20 \mathrm{bA}$ & $8185.20 \mathrm{bB}$ & $21742.82 \mathrm{aA}$ & $13362.80 \mathrm{aA}$ \\
\hline 30 & $12520.40 \mathrm{bA}$ & $6649.60 \mathrm{bB}$ & $12142.00 \mathrm{bA}$ & $11951.60 \mathrm{abA}$ \\
\hline $4 \stackrel{0}{4}$ & $23010.80 \mathrm{aA}$ & $26090.80 \mathrm{aA}$ & $10854.00 \mathrm{bB}$ & $11951.60 \mathrm{abA}$ \\
\hline \multicolumn{5}{|c|}{$200 \mathrm{~kg} \mathrm{ha}^{-1}$} \\
\hline \multirow{2}{*}{ Cuts } & \multicolumn{4}{|c|}{ Years } \\
\hline & 2013 & 2014 & 2015 & 2016 \\
\hline 10 & $15052.00 \mathrm{bA}$ & $9059.20 \mathrm{bB}$ & $16854.40 \mathrm{aA}$ & $10452.40 \mathrm{aB}$ \\
\hline 20 & $14367.20 \mathrm{bA}$ & $10452.00 \mathrm{bB}$ & $16018.96 \mathrm{aA}$ & $14012.80 \mathrm{aAB}$ \\
\hline 3우 & $11756.00 \mathrm{bA}$ & $7101.20 \mathrm{bB}$ & $14396.00 \mathrm{aA}$ & $13506.80 \mathrm{aA}$ \\
\hline $4 \stackrel{0}{2}$ & $23896.80 \mathrm{aA}$ & $19461.20 \mathrm{aB}$ & $13162.00 \mathrm{aC}$ & $13506.80 \mathrm{aC}$ \\
\hline \multicolumn{5}{|c|}{$250 \mathrm{~kg} \mathrm{ha}^{-1}$} \\
\hline \multirow{2}{*}{ Cuts } & \multicolumn{4}{|c|}{ Years } \\
\hline & 2013 & 2014 & 2015 & 2016 \\
\hline 1 우 & $18612.00 \mathrm{bA}$ & $15444.80 \mathrm{bA}$ & $17236.80 \mathrm{bA}$ & $10566.00 \mathrm{bB}$ \\
\hline 20 & $15651.20 \mathrm{bcB}$ & $10568.00 \mathrm{cC}$ & $25205.23 \mathrm{aA}$ & $14138.00 \mathrm{abBC}$ \\
\hline 3은 & $13569.60 \mathrm{cA}$ & $9617.20 \mathrm{cB}$ & $13587.20 \mathrm{bA}$ & $15699.20 \mathrm{aA}$ \\
\hline 40 & $22763.20 \mathrm{aA}$ & $26090.80 \mathrm{aA}$ & $9030.00 \mathrm{cC}$ & $15699.20 \mathrm{aB}$ \\
\hline \multicolumn{5}{|c|}{$300 \mathrm{~kg} \mathrm{ha}^{-1}$} \\
\hline \multirow{2}{*}{ Cuts } & \multicolumn{4}{|c|}{ Years } \\
\hline & 2013 & 2014 & 2015 & 2016 \\
\hline 10 & $19468.00 \mathrm{bA}$ & $17881.20 \mathrm{bA}$ & $20423.20 \mathrm{aA}$ & $11409.60 \mathrm{bB}$ \\
\hline 20 & $17854.00 \mathrm{bcA}$ & $10042.80 \mathrm{cB}$ & $21636.70 \mathrm{aA}$ & $17626.80 \mathrm{aA}$ \\
\hline 3ㅇ & $14063.60 \mathrm{cA}$ & $9600.00 \mathrm{cB}$ & $13538.40 \mathrm{bA}$ & $15441.60 \mathrm{aA}$ \\
\hline 4운 & $24175.60 \mathrm{aB}$ & $28302.40 \mathrm{aA}$ & $12903.20 \mathrm{bC}$ & $15441.60 \mathrm{aC}$ \\
\hline $\mathrm{CV}(\%)$ & \multicolumn{4}{|c|}{22.54} \\
\hline
\end{tabular}




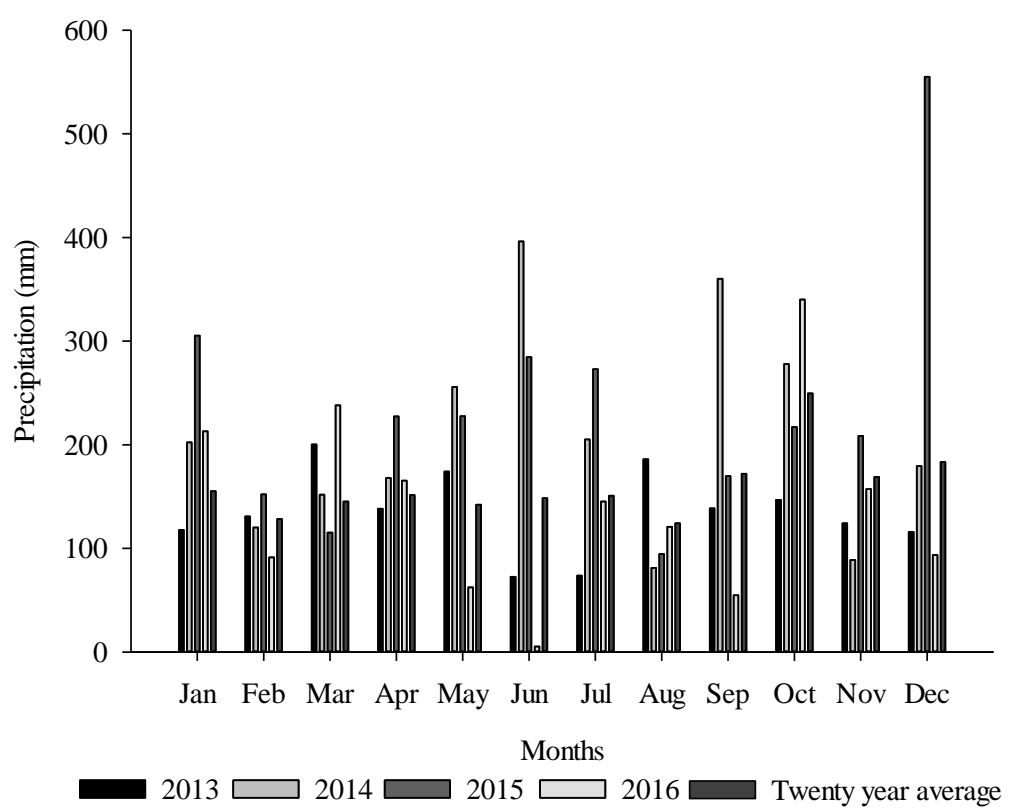

Fig 1. Cumulated rainfall for 2013, 2014, 2015, 2016 agricultural years, and average of the last 20 years, stratified for the months of trials conduction.
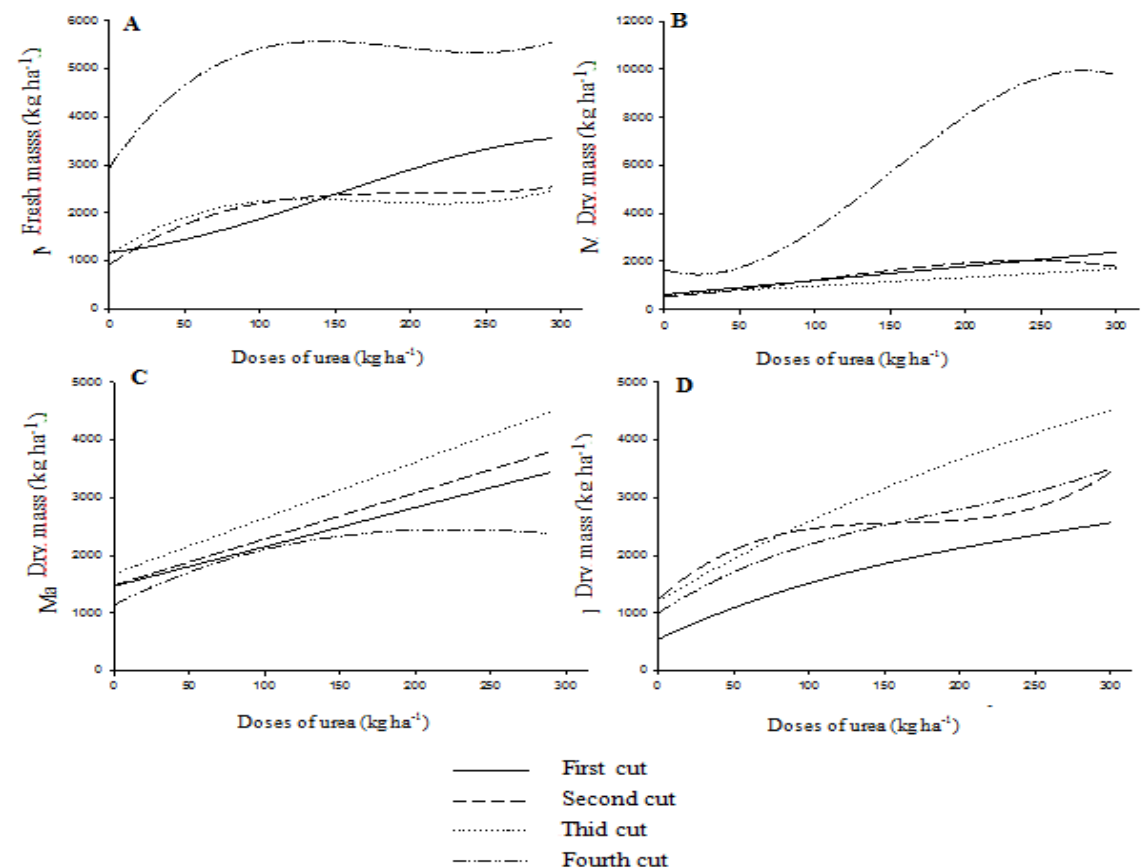

Fig 2. Average dry biomass production of natural re-sowing ryegrass submitted to nitrogen fertilization doses over four agricultural years 2013 ; 2014 B; 2015 C and 2016 D.

Table 3. Efficiency of nitrogen utilization of natural re-sowing ryegrass during four agricultural years.

\begin{tabular}{|c|c|c|c|c|c|}
\hline \multirow{4}{*}{$\begin{array}{l}\text { Doses of nitrogen } \\
\text { fertilization (kg of } \\
\text { urea/ha/year) }\end{array}$} & \multicolumn{4}{|c|}{ Efficiency of nitrogen utilization ( $\mathrm{kg}$ of DM/kg of urea applied) } & \multirow[b]{4}{*}{ Mean } \\
\hline & \multicolumn{4}{|c|}{ Agricultural years } & \\
\hline & 2013 & 2014 & 2015 & 2016 & \\
\hline & & & & & \\
\hline 50 & 76.6 & 55.6 & 41.0 & 57.2 & 57.6 \\
\hline 100 & 53.1 & 51.3 & 39.3 & 46.8 & 47.6 \\
\hline 150 & 42.2 & 43.1 & 39.0 & 41.6 & 41.5 \\
\hline 200 & 37.7 & 53.6 & 32.0 & 34.8 & 39.5 \\
\hline 250 & 26.3 & 51.9 & 28.9 & 34.2 & 35.3 \\
\hline 300 & 27.8 & 48.4 & $33.6 b$ & 33.2 & 35.8 \\
\hline
\end{tabular}




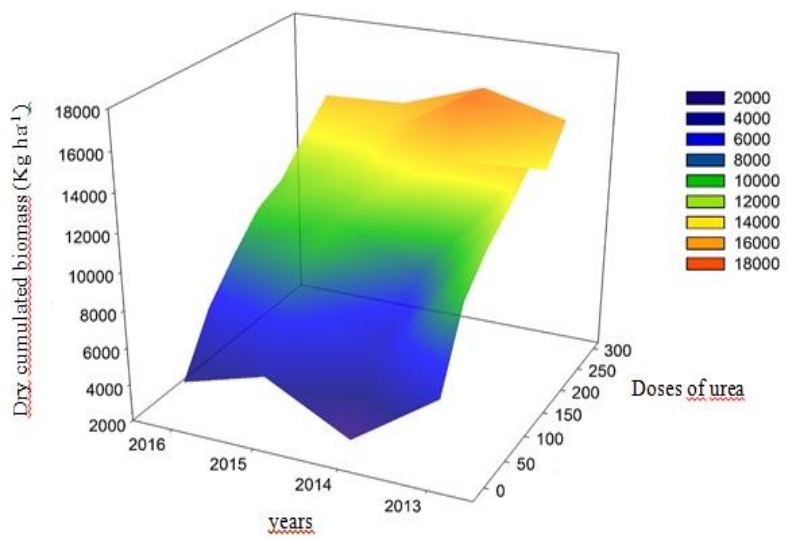

Fig 3. Production of accumulated dry biomass of natural re-sowing ryegrass submitted to different nitrogen fertilization doses during four agricultural years.

third leaf expansion, and the other three after each cut, all corresponding to the respective doses tested.

The criterion for cutting was based when the plants expressed canopy average height of $30 \mathrm{~cm}$, where yield estimates were supported by the sampling of $0.25 \mathrm{~m}^{2}$ through a pre-defined frame with dimensions of $25 \times 25 \mathrm{~cm}$, being it randomly placed in the useful area of each experimental unit. After, the rest of the plot was mowed with $10 \mathrm{~cm}$ residue for regrowth (Carvalho et al., 2015). After the cuts, the samples were taken to the laboratory for weighing, and then placed in oven at $65^{\circ} \mathrm{C}$ until constant mass. Subsequently, it was obtained the production of dry biomass (DB) ( $\mathrm{kg} \mathrm{ha}^{-1}$ ) and nitrogen utilization efficiency ( $\mathrm{kg}$ $\mathrm{ha}^{-1}$ ) (NUE) in $\mathrm{kg}$ of dry matter per kg of $\mathrm{N}$ applied (Silveira et al., 2013).

\section{Statistical analysis}

The data were submitted to analysis of variance in order to verify the assumptions of the statistical model. Subsequently, the interaction between agricultural years $x$ harvesting times $x$ nitrogen doses at $5 \%$ of probability of error was tested. When significance was identified for qualitative factors, they were sliced into simple effects (agricultural years and harvesting times). In the same way, a linear regression analysis was performed, identifying the highest significant degree of the polynomial for each level of the quantitative factors at $5 \%$ of probability by the $t$ test. The estimates obtained for nitrogen utilization efficiency (NUE) were considered as a mean tendency expressing a descriptive trait.

\section{Conclusion}

The application of nitrogen on natural re-sowing ryegrass promotes the increase in dry biomass production across agricultural years. The use of nitrogen as topdressing showed little effect on the persistence of ryegrass plants in the four years of study. The efficiency of nitrogen utilization was inversely proportional to the increment of the nitrogen doses used. It is fundamental to understand the behavior of nitrogen fertilization in pastures with natural re-sowing and its effects on the persistence of the plants throughout agricultural years, as well as their participation in the sustainability of agricultural activity.

\section{Acknowledgements}

The authors wish to thank the National Council for Scientific and Technological Development (CNPq), and the Coordination for the Improvement of Higher Education Personnel (CAPES), for the support.

\section{References}

Ahrens DC, Oliveira JC (1997) Efeito do manejo do azevém anual (Lolium multiflorum L.) na produção de sementes. Revista Brasileira de Sementes. 19(1):41-47.

Assmann AL (2002) Adubação nitrogenada de forrageiras de estação fria em presença e ausência de trevo branco, na produção da pastagem e animal em área de integração lavoura pecuária. Curitiba: Universidade Federal do Paraná - Setor de Ciências Agrárias, 2002. 100p. Tese (Doutorado em Agronomia) - Universidade Federal do Paraná, 2002.

Barbosa CMP, Carvalho PCF, Cauduro GF, Devincenzi T, Nabinger C, Jacques AVA (2008) Efeito de métodos e intensidades de pastejo sobre a ressemeadura natural de azevém anual. Acta Scientiarum Animal Sciences. 30: 387393.

Barth Neto A, Carvalho PCF, Lemaire G, Sbrissia AF, Canto MW, Savian, JV, Amaral GA, Bremm C (2013) Perfilhamento em pastagens de azevém em sucessão a soja ou milho, sob diferentes métodos e intensidades de pastejo. Pesquisa Agropecuária Brasileira. 48(3): 329-338.

Cantarella, H (2007) Nitrogênio. In: Novais RF, Alvarez VVH, Cantarutti RB, Neves JCL. (Ed.). Fertilidade do solo. Viçosa: Sociedade Brasileira de Ciência do Solo. 375-470.

Carambula M (1977) Producción y manejo de pasturas sembradas. Montevidéo, Editorial Hemisfério Sur. 464 p.

Carvalho IR, De Souza VQ, Nardino M, Follmann DN, Schmidt D, Baretta D (2015) Correlações canônicas entre caracteres morfológicos e componentes de produção em trigo de duplo propósito. Pesquisa Agropecuária Brasileira. 50(8): 690-697.

Confortin ACC (2009) Dinâmica do crescimento de azevém anual submetido a diferentes intensidades de pastejo. 98 f. Dissertação (Mestrado em Zootecnia), Programa de PósGraduação em Zootecnia, Universidade Federal de Santa Maria. Santa Maria, RS.

Cordeiro LAM, Balbino LC, Galerani PR, Domit LA, Silva PC, Kluthcouski J, Vilela L, Marchão RL, Skorupa LA, Wruck FJ (2015) Transferência de Tecnologias para Adoção da 
Estratégia de Integração Lavoura-Pecuária Floresta. Brasília, DF: Embrapa, 2015. p. 377-393.

Costa NL, Paulino VT, Magalhães JA, Rodrigues BHN, De Seixas Santos FJ (2016) Eficiência do nitrogênio, produção de forragem e morfogênese do capim-massai sob adubação. Nucleus. 13(2): 173-182.

Da Silva SC, Nascimento Júnior D (2007) Avanços na pesquisa com plantas forrageiras tropicais em pastagens: características morfofisiológicas e manejo do pastejo. Revista Brasileira de Zootecnia, 36 suplemento especial, 121-138.

EMBRAPA - Empresa Brasileira de Pesquisa Agropecuária (2013) Centro Nacional de Pesquisas de Solos. Sistema Brasileiro de Classificação de Solos. 3ed. Rio de Janeiro.

Hirakuri MH, Debiasi H, Procópio SO, Franchini JC, Castro C (2012) Sistemas de produção: conceitos e definições no contexto agrícola. Londrina: Embrapa Soja, 24. (Embrapa Soja. Documentos, 335).

Medeiros RB, Nabinger C (2001) Rendimento de sementes e forragem de azevém anual em resposta a dose de nitrogênio e regimes de cortes. Revista Brasileira de Sementes, 23(2): 245-254.

Mittelmann A, Montardo DP, Castro CM, Nunes CDM, Buchweitz ED, Corrêa BO (2010) Caracterização agronômica de populações locais de azevém na Região Sul do Brasil. Ciência Rural. 40(12): 2527-2533.

Ost HJ (2013) Componentes do rendimento e qualidade de sementes de Paspalum guenoarum Arech. ecótipo" Azulão" submetido a diferentes regimes de cortes. $74 \mathrm{p}$. Tese de Doutorado. Dissertação (Mestrado em Zootecnia) - Faculdade de Agronomia, Universidade Federal do Rio Grande do Sul, Porto Alegre.

Overbeck GE, Hermann JM, Boldrini II, Kiehl K, Kirmer A, Koch C, Kolmann J, Meyer ST, Müller SC, Nabinger C, Pilger GE, Trindade JPP, Vélez-Martin E, Walker EA, Zimmermann DG, Pillar VD (2013) Restoration ecology in Brazil - time tostep out of the forest. Natureza and Conservação. (11):92-95.
Parsons AJ (2011) Past lessons and future prospects: plant breeding for yield and persistence in cool-temperate pastures. Grass Forage Science. (66): 153-172.

Rowarth JS, Boelt B, Hampton JG, Marshall AH, Rolston MP, Sicard G, Silberstein J. R, Young WC (1998) The relationship between applied nitrogen, nitrogen concentration in herbage and seed yield in perennial ryegrass (Lolium perenne L.) I. Cv. Grassland Nui at five sites around de globe. Journal of Applied Seed Production. (16): 105-114.

Seepaul R, Bisoondat M, Reddy KR, Evans WB (2016) Nitrogen Application Rate and Genotype Effects on Switch grass Production and Chemical Characteristics. American Journal of Plant Sciences. (7): 533-546.

Sicard, G (1995) Nitrogen fertilization, nitrogen uptake and seed yield in perennial ryegrass. Journal of Applied Seed Production. 13, p64.

Silveira ML, Vendramini JMB, Sellers B, Monteiro FA, Artur AG, Dupas E (2013) Bahia grass response and $N$ loss from selected $\mathrm{N}$ fertilizer sources. Grass Forage Science. 70, 154-160

Sociedade Brasileira de Ciência do Solo (2016) Manual de adubação e calagem para estados do Rio Grande do Sul e Santa Catarina/ Sociedade Brasileira de Ciência do Solo Núcleo Região Sul. Comissão de Química e Fertilidade do Solo - RS/SC, 2016. 376p.

Szareski VJ, Carvalho IR, Nardino M, Demari GH, Pelegrin AJ, Ferrari M, Meira D, Quadros ES, Kehl K, Pedo T, Zimmer PD, Souza VQ, Aumonde TZ (2016) Ethyl Methane Sulfonate and its effects on morphological traits of dual pourpose wheat. International Journal of Current Research. 8: 39707-39713.

Taiz L and Zeiger E (2013) Fisiologia vegetal. 5.ed. Porto Alegre: Artemed, 954p.

Young WCII, Youngberg HY, Chilcote DO (1996) Spring nitrogen rate and timing influence on seed yield componentes of perennial ryegrass. Agronomy Journal. Madison, 88 (4): 947-951.

Youngberg $H$ (1980) Techniques of seed production in Oregon. In: Hebbleth waite, PHD. (ed.). Seed production. London: Butter worths. p.203-213. 